\title{
保持型ロボティック ユーザインタフェースの研究
}

\section{清水 紀芳*1・小泉 直也*1・杉本 麻樹*1・新居 英明*1・ 関口 大陸 $* 2$ ・稲見 昌彦*1*3}

\begin{abstract}
従来ロボットは製造業等の現場において人の身代わりとして何らかの作業を行うという目的で研究が進めら れていた。これに対しUIとしてロボットを用いる概念がRUI-Robotic User Interface-として提案されてい る。本研究では RUI を使用した，身体性を持った保持型の力覚提示装置を提案する。また，RUI を通して情報 世界とインタラクションするためのシステムの試験的な実装を行った。
\end{abstract}

キーワード：ロボティックューザインタフェース, 触覚提示, エンタテインメント，バーチャルリアリティ

\section{1. 序論}

現在，パーソナル・コンピュータではグラフィカル ユーザインタフェース(GUI)が広く用いられている.そ れに対し近年では，GUI とは異なる新たな形のインタ フェースとして，我々人間が生活している実世界のメ リットを生かしつつ情報世界とシームレスに接続する ことを目指した，実世界指向のインタフェースが活発 に研究されている $[1][2]$.

一方ロボットは, 作業の效率化やオートメーション 化を狙った産業用口ボットや，人にとって過酷で危険 な環境下においてなんらかの作業を行わせる極限環境 ロボットといったように，「人の代わり」として何らか の作業を行うという目的で研究が進められてきた。し かし近年，ロボットが人にとって身近なものとなり， ペットロボットやヒューマノイド，介護ロボットとい つたように，「人に働きかける」ことを目的とした人間 共存型のロボットが登場している.

このロボットは身体性を有するコンピュータである

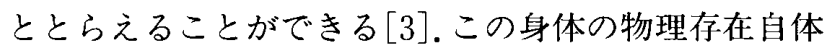
が圧倒的な存在感となるとともに，身体を用いな物理 的相互作用を通し，実世界に対し大きな影響力を発揮 することができる。このロボットを，実世界と情報世

$\dagger$ Teddy bear-like Robotic User Interface

Noriyoshi SHIMIZU, Naoya KOIZUMI, Maki SUGIMOTO, Hideaki NII, Dairoku SEKIGUCHI, Masahi ko INAMI

*1 電気通信大学大学院 電気通信学研究科 知能機械工学専攻 Graduate School of The University of Electro-Communications

*2 東京大学大学院 情報理工学系研究科

School of Information Science and Technology, The University of Tokyo

*3 科学技術振興機構 さきがけ

Japan Science and Technology Agency
界とのインタフェースとしてとらえた概念がロボティ ックューザインタフェース $(\mathrm{RUI})$ として提案されている [4]. RUI を用いることにより, 実世界に対しての入力 と出力を兼ね備えた実世界指向のユーザインタフェー ス環境を構築できると考えられている。

また RUIは，ヒューマノイド（人型ロボット）を利 用したインタフェース, 直感的なインタラクションデ ザイン，身体性を有した提示装置，といった 3 つ点 に関して新規性を有する。

・ヒューマノイドを利用したインタフェース

従来のヒューマノイドは数十 $\mathrm{cm}$ から人と同等サイズ といったものであり，自律，他律で動作を行わせるた めのものであった.これに対し RUI は, ヒューマノイ ドを人と同様の身体性を持ったインタフェースとして 利用する。操作者はヒューマノイドを手で持ちながら， ヒューマノイドの手足等を動かして入力を行い，それ と同時にヒューマノイド自体の動作から出力を得る. よって RUI に用いるヒューマノイドは,人の手で持つ ことができるサイズであり，人の手で楽に操作が可能 であるバックドライバビリティを有する必要がある。 このようなUIとして使用する目的で設計されるヒュー マノイド自体，新規性を有するものと言える.

・直感的なインタラクションデザイン

人が情報世界とインタラクションを行う際の入力方 法は大きく分けて二種類ある。まず，格闘ゲームやロ 一ルプレイングゲーム等に見られるような，情報世界 内のアバ夕をジョイスティックやジョイパッド等を用 いて操作し，アバ夕を通して間接的に入力を行う方法, もう一つはEyeToy ${ }^{\mathrm{TM}}[5]$ に見られるような, 人の身体 動作を用いて直接的に入力を行う方法である。人に対 しての出力方法としては，直接人の視覚・聴賞に訴え かけるものが主である。また，フォースフィードバッ 
クと㭔ばれる触覚に対する出力は，エンタテインメン 卜分野においてはジョイスティックの振動や抵抗感と いった提示しか実現されておらず，我々が日常作業で 手がかりとしている触覚情報とは遥かにかけ離れてい た。これに対し RUIでは，情報世界に存在する人型の アバ夕と同形状の身体性を持った RUI を現実世界に用 意し, RUI と・アバ夕とで形状同期を行わせる。この RUI を操作することで，人は情報世界に対しての入力が可 能となると同時に，情報世界のアバ夕と同期した RUI 自身の動作による出力を得ることができる。また，自 己の身体像を外在させたものと言える RUI を入出力装 置に利用することで，人が成長過程において獲得する 身体図式を用いた直感的な入力, RUI 自身の動作によ る視覚・触觉情報の提示，といったことを可能とする。

・身体性を有した提示装置

RUIは身体性を持つがゆえに，自己を投射した身体 像とみなすことができる。このため RUI を通して人に 対して触覚提示を行うということが可能となる．人に 対する従来の触覚提示方法としては, 人の体に装置を 装着させたり人が装置を手で把持して操作するなどし て，人の体に対して直接的に力の大きさや方向を提示 するという方法であった。これに対し RUIは，人が手 で保持し，操作しているRUI 自身の動作を用いること で間接的に人に对して触覚提示を行うことができる。

更にRUI は身体性を持つため, 人の身体图式や触覚を 利用し，操作者はRUI を見ることなく保持している手 の感覚によって RUI の形状情報を得ることができ，ま た RUI 自身の動作や形状という視覚情報を眼から得る ことでアバ夕の状態を知ることが可能である。つまり RUI は触覚提示装置でありながら, 形状提示, 視覚提 示も可能とする提示装置であると言える。

このようにヒューマノイド（人型ロボット）を用い た RUIは, 物理世界との相互作用が可能, ロボットの 形状や動作による視覚的な情報提示， ロボットから人 に力を加えることによる力觉的な情報提示, 人の側が 值接口ボットに触れて形状を変化させることによる指 示入力, といった特徴を持つ.

本研究では，従来存在するような「装着型」，「把持 型」,「遭遇型」の力覚を提示するインタフェースとは 異なり，RUIを使用した身体性を有する保持型の力営 提示装置を開発する。また, 力觉提示装置としての RUI をエンタテイメント分野で利用寸るために必要な, 物 理モデルを組み込んだアプリケーションの開発を行う。

つまり，RUI をインタフェースとして使用したエン タテイメント的アプリケーションの試験的実装を目的 とする。

\section{2. 保持型ロボティックユーザインタフェース}

保持型ロボティックユーザインタフェースとは, 操 作者が両手で人型ロボットを持ちながらロボットの手 足等を操作することで，口ボットを通じて情報世界と インタラクションを行える身体性を有したインタフェ ースである.

この保持型 RUIについて GUI と対比し, 具体的に説 明する. GUI では入力としてマウスやキーボードを用 い, 出力としては入力の結果がグラフィックとしてデ イスプレイに表示される。これに対して RUIにおける 入出力方法は，ロボットを人が動かすことが入力とな り，ロボット自身が動作することが出力になるという， 入出力にロボットを用いたものである。つまり，言語 やシンボル操作を主体とした象徵的表象を用いるのが GUIだとすると，人間が成長の過程において，より早 期に獲得する身体四式や身体像を用いた動作的表象や 映像的表象を主として用いるのがRUIであるといえる。

エンタテインメント的なアプリケーションに扔いて, GUI とRUIのどちらが適しているかを考える。先に述 べたように GUIは言語やシンボル操作を主としたもの であり，マウスやキーボード等のインタフェースを使 用した場合では，デスクトップトのファイル等をマウ スで選択して開き，キーボードを用いて文章を書く， といったようなデスクワークに関するアプリケーショ ンが適していると考之られる。一方 RUI は，身体図式 や身体像を用いた動作的表象を主としており，身体性 を持った人型のロボットをインタフェースとして使用 する，よって，ゲーム内に操作者のアバ夕が存在して おり，それを操作するといった現在のほとんどのゲー ムにおいて，人型ロボットを使用することで直感的な 入力, 触鸴・形状・視覚情報の提示といったことが可 能となる.よって GUI と比較するとRUI のほうがアバ タベースのエンタテインメント的なアプリケーション に適していると考えられる。

RUI をエンタテインメント的なアプリケーションに 使用した場合として，ボクシングゲームに扔いて既存 のゲームインタフェースと RUI を用いな場合を想定す る。

表 1 GUI と RUI

\begin{tabular}{|c|c|c|}
\hline & GUI & RUI \\
\hline 人力 & マウス・キーボード & ロボットを動かす \\
\hline 出力 & ディスプレイ & ロボットの動作・形状 \\
\hline $\begin{array}{l}\text { アプリケ } \\
\text { ーション }\end{array}$ & デスクワーク & エンタテインメント \\
\hline メタファ & デスクトップ & 人の身体 \\
\hline
\end{tabular}




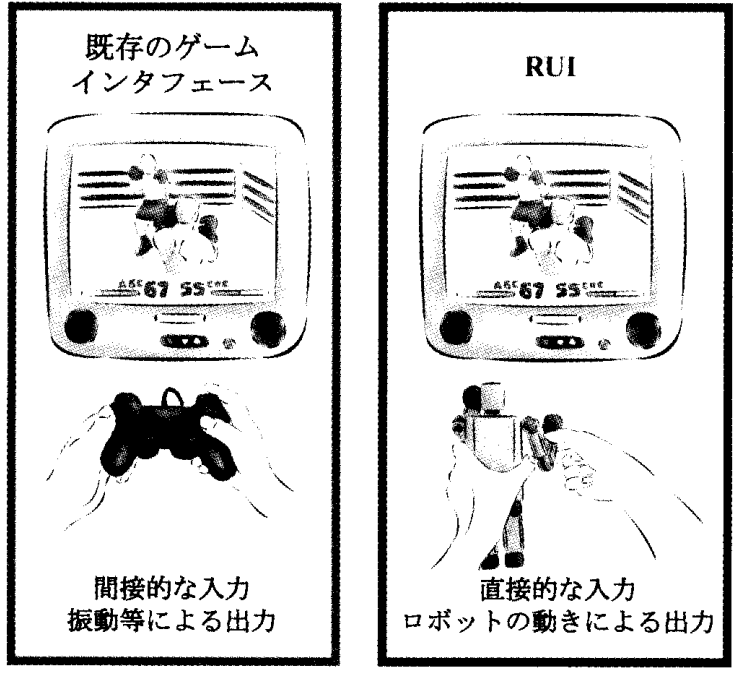

図 1 既存のゲームインタフェースと RUI

既存のゲームインタフェースでは, ゲームの中のキ ヤラク夕を動か寸場合には十字キーなどを押して動作 させるまた，パンチやガードといった動作をキャラ ク夕に行わせる場合は，その動作に相当するボタンを 押すことになる。これより既存のゲームインタフェー スを用いた場合には，間接的な入力によって操作して いるということがわかる．出力としては，ゲーム内の 自分のキャラクタが敵キャラク夕に殴られた時に、イ ンタフェースが振動するといったものが考えられる。

一方 RUI では,ゲーム内のキャラク夕と同形状の口 ボットを用意し，キャラクタとロボット間において形 状同期を行う。これにより，キャラクタにパンチなど の動作を行なわせたい場合には，人がロボットをその ように動かすことによって，直接的にキャラク夕の動 作を指示入力することができる．また，出力には振動 といった提示だけでなく，キャラク夕が敵キャラク夕 に顔などを殴られた場合は，口ボット自体のその殴ら れた所と同じ箇所が動作する。これにより，ロボット 自体の動作やモーションによる視覚的な情報提示とい ったことも可能となる.

格闘ゲーム，ロールプレイングゲーム，アクション ゲーム等，現在のゲームのほとんどは操作者自身のア バ夕を操作するものである。このようなアバ夕を用い るゲーム全てに対して RUIは，直接アバ夕を操作する ための入出力装置としての利用や，現状のインタフェ 一スを補完する形での利用が可能である。また，コミ ユニケーションを含む MMORPG 等ネットワーク型エ ンタテイメントといったものに対しても RUI を使用す ることで, ジェスチャや触覚を伴うコミュニケーショ ンを可能とする.

次に, RUI を力覚提示装置として使用した場合と既
存の力覚提示装置との違いについて述べる. 力覚を提 示するインタフェースとして, PHANToM[6]や SPIDAR[7]などがある. PHANToM とは, 指に装着 した状態で操作し，バーチャルリアリティ空間内の物 体に触れると, 装置に仕込まれたアクチュエータが人 間の運動を拘束することで，そこに物体があるという 感覚を作り出す. SPIDAR は, 四つの支点からプーリ 一を経由して直線的に張られた四本の系が取り付けら れたリングを指にはめて操作する装置であり, 系が抵 抗して反力が伝わる仕組みである。これら以外にも様々 な力覚提示装置が存在するが, それらは前述の通り大 別して,「装着型」,「把持型」「遭遇型」といった三つ の型に分類することが可能である.上で触れた PHANToM と SPIDAR は装着型に分類される。

RUIを用いることで, 既存のPHANToM や SPIDAR ど「装着型」,「把持型」,「遭遇型」に分類 される力覚提示装置とは違った，身体性を有した「保 持型」の力党提示装置が開発出来る. RUI を力覚提示 装置として使用した場合, 従来の力覚提示装置との間 には次のような違いが存在する，考えられる点は以下 の三つである。

一つ目は, 力覚の提示方法である。従来では人の体 に装置を装着させたり人が装置を手で把持して操作し, 人の体に刘して直接的に力の大きさや方向を提示する. 一方 RUIでは，身体性を有した装置を人が手でもって 操作し, RUI 自体の動きを通じて持っている人に対し て力を提示する。つまり RUIでは, 従来のように直接 的ではなく間接的に力覚が提示される。

二つ目は, VR 空間とのインタラクションの方法であ る.従来では人自身が直接的に実世界と同サイズのVR 空間にインタラクションするものであった. だが RUI では, RUI をVR 空間内に存在させ, その RUIを人間 が操作することでインタラクションする.

三つ目は，力覚提示装置で使用するアプリケーショ ンの違いである，従来のものであれば，その装置の形 状・使用法に沿ったアプリケーションを実行するしか なかった。つまり，装置がペン型となっていればペン としてVR 空間にインタラクションするのみであった。 対して RUIでは, 人間を投影したRUIアバ夕がVR 空 間に存在しそその RUI アバ夕に様々なツールを持たせ ることも可能である。これによって一つの装置に対し て様々なアプリケーションを用意することができ，装 置としての沉用性が高いことがわかる.

これら力覚提示方法と VR 空間に対するインタラク ション方法, 装置の沉用性が, 従来の力覚提示装置と RUI を力党提示装置として使用する上での大きな違い であると考えられる。 


\section{RUI 構成}

力覚提示装置として使用可能なロボティックューザ インタフェース-RUI-として, RobotPHONEがある [8]. RobotPHONEは対称型のマスタースレーブ制御を用い ることで，遠隔地に離れな二対の RobotPHONEを繫 いで形状同期を行うことができるものである。

この RobotPHONEを用いることで，遠隔地の人同 土がお互いに打を伝え合ったり，ジェスチャを用いた コミュニケーションを可能とする.

この RobotPHONEに対して今回製作する RUIは, 実世界に存在するRUI と, PC内の物理モデル世界に 存在する RUI アバ夕とを繫いで形状同期を行うもの,

と言うことができる。

「保持型」の RUIは, 操作者がRUIを両手で持ちな がら操作し, 情報世界とインタラクションを行うなめ のものである。このために最低限必要な自由度を満た すものとして, 上半身のみで片腕が 2 自由度, 両腕で 合計 4 自由度と設定した。

RUIはアバ夕と形状同期を行うものであり, RUIの

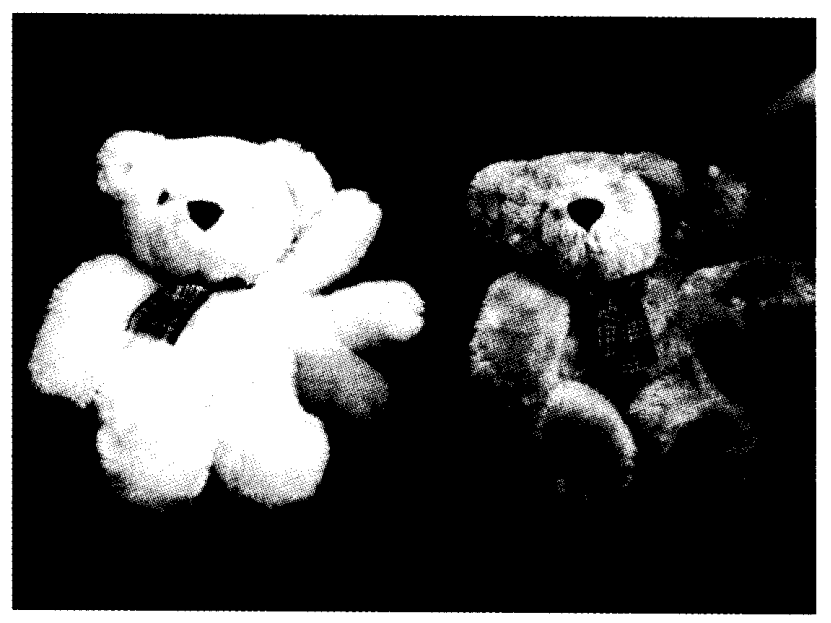

図 2 RobotPHONE の形状同期
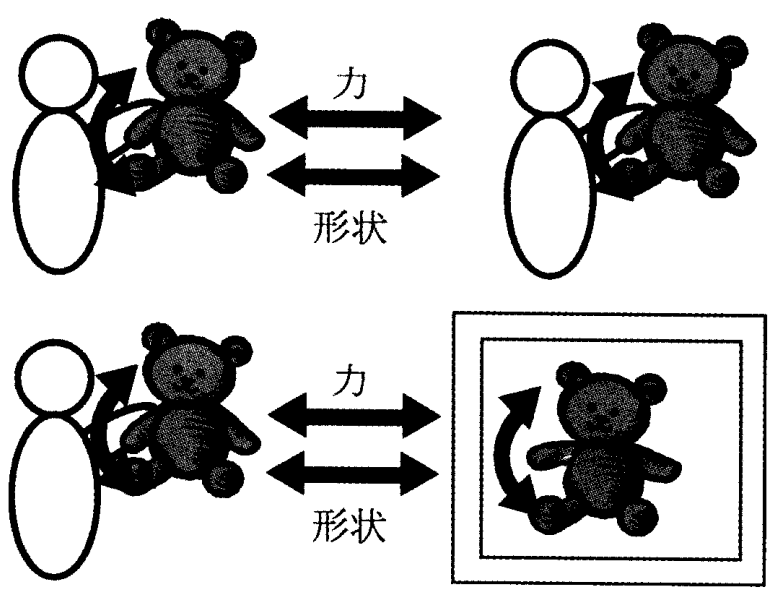

図 3 RUI の形状同期

上-RobotPHONE 下-提案する RUI
関節角の検出と関節の駆動を行うことが必要である。 今回は, 関節角検出用のポテンショと関節駆動用のモ ータが一つのユニットとして構成されているサーボモ 一夕を改造して利用することで，簡単な機構での実装 を可能とした。

また, 今回の保持型 RUI は両手で持ちながら RUI の 関節を動かして操作すると同時に，RUIを持っている 手を通して人は触覚や形状情報を得ることができ, RUI 自身の形状や動作を目で見ることで視覚情報を得るこ とができる。よって，関節動作時に抵抗が少なくバッ クドライバビリティを有するサーボモー夕を選択, RUI の操作性や身体性を失わないように全体の各パーツの 寸法を設定, 外観を考虑して機構を縫いぐるみ内に内 蔵させるといった実装を行った。

RUIの各関節には市販の小型ラジコンサーボ(GWS 製 MICRO-MG）を改造したポテンショ内蔵の小型ギ アドモータを使用した。そのモータは，駆動用に自作 のサーボ回路を使用して PWM 駆動とし, ワンボード マイコンを使用して制御を行う。そして, RUI と PC 内 の RUIアバ夕は,ポテンショの值を利用して各関節を 動作させ，形状同期を行う。

今回製作した RUI の寸法等の仕様は次の通りである。 腕パーツの長さが $94 \mathrm{~mm}$, 体の幅が $76 \mathrm{~mm}$, 両腕を広げ な状態での右腕の先端から左腕の先端までの長さが 267 $\mathrm{mm}$, 腕の関節から先端まで(腕関節のサーボへッドの 中心から腕パーツの先端まで）の長さが $70 \mathrm{~mm}$ となっ ている。また, 重量は $260 \mathrm{~g}$, 各関節のモー夕の減速比 は410分の 1 , 提示可能反力は $6.4 \mathrm{kgf} \cdot \mathrm{cm}$ となってい る。操作者が RUIの関節を曲げるときに必要なトルク は測定の結果， $0.69 \mathrm{kgf} ・ \mathrm{~cm}$ であった，若干，操作時 に重さを感じるものの大人から子供まで十分操作可能 なバックドライバビリティであると考えられる。

RUIは操作者に対して力覚提示を行えるものである. 実際に製作したRUIにおいてどの程度の力提示が可能 であるか,サーボに入力する電流值を変化させて発生 したトルクの測定を行った。なお，サーボ駆動用の電 源はDC6Vである。

測定の結果, 410 分の 1 という大きな減速比のサーボ

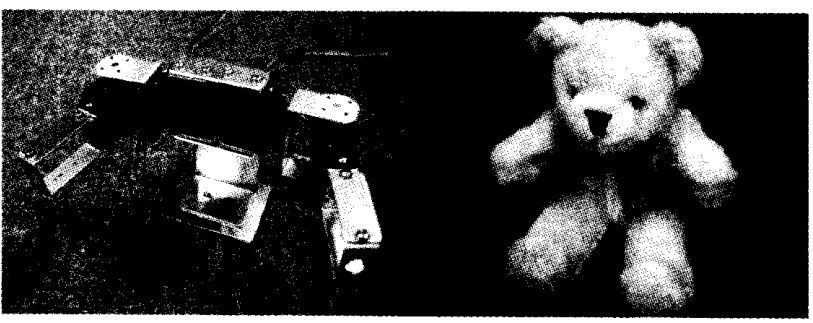

図 4 製作した RUI 左一内部機構 右一外観 


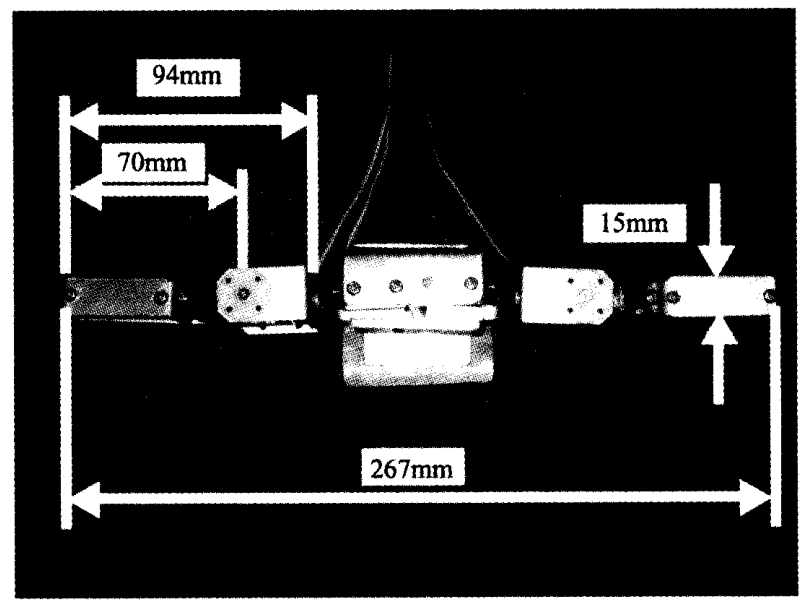

図 5 製作した RUI 寸法（上面図）

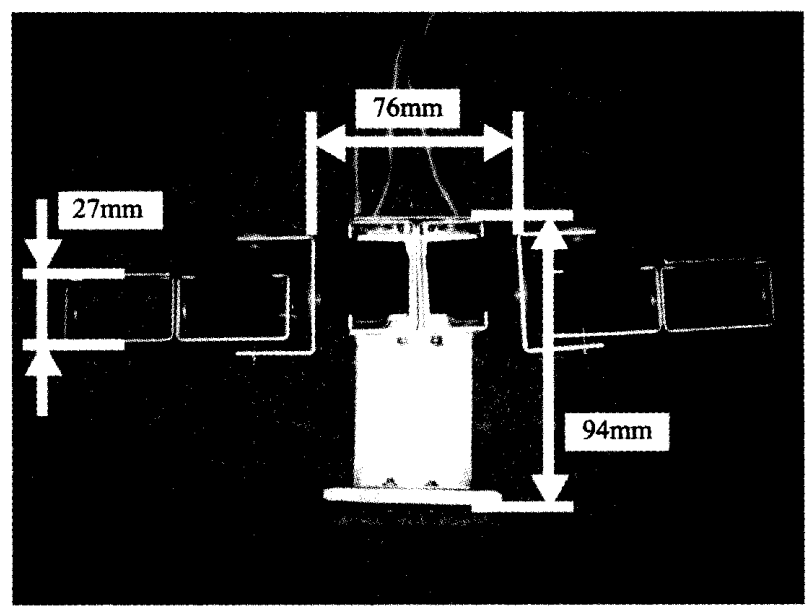

図 6 製作したRUI 寸法（正面図）

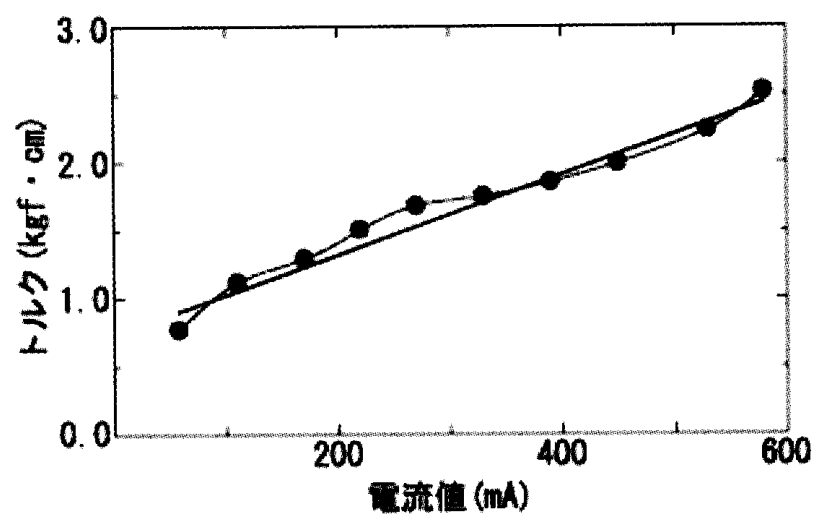

図 7 電流值とトルクの関係

であるが，図７のように概ね電流值とトルクの比例関 係を得た。また本システムにおけるトルク提示の幅は 約0.7〜2.7 (kgf・ cm)であることが分かった.

\section{4. 物理モデル}

\section{1 離散時間系運動方程式}

コンピュータで物体の運動をシミュレートする場合
には，運動方程式を離散的に解く必要がある。今回は， リアルタイム処理に適した方法としてオイラー法を使 用した。

また，今回製作する物理モデルは，RUI を通じて情 報世界において静止している物体ではなく，何らかの 動作を行っている物体に対してインタラクションが可 能であるものとして，今回は二次元平面内で並進・回 転運動を行う物体に対してインタラクションが可能で あるエアホッケーを選択した。

このエアホッケーでは，パックは薄い円盤として二 次元平面で並進回転を行っているものとする，ストラ イカーはパックと同一の二次元平面において, RUI モ デルの腕の根元から先端までを半径とした円周上を， RUI の腕を左右方向に動作させるサーボのポテンショ 值に従って動作する。また，RUIの関節制御は P 制御 で行う。ストライカーがパックに衝突した時の操作者 への力党提示に関しては, 今回製作した保持型 RUI の 腕の機構は直交した二軸リンクのため二次元方向への 力覚提示は行えない，よって，ストライカーの円軌道 の接線方向に対してストライカーがパックから受ける 力を求め, その力の值に応じて RUI の左右方向に動作 するサーボの動作目標値を設定する，その目標做に従 って RUIの腕を回転させることで, 操作者に対して力 覚提示を行う。

エアホッケーの物理モデルを製作する上で，剛体で あるパックの運動方程式が必要となる。パックの二次 元の回転・並進の運動方程式を解いた結果として得ら れた，以下の (1) 〜 (6)の6つの式を用いてパックの運 動の計算を行った。

$$
\begin{aligned}
& x(t+d t)=x(t)+v x(t) d t \\
& y(t+d t)=y(t)+v y(t) d t \\
& v x(t+d t)=v x(t)+\frac{F \cos \theta}{m} d t \\
& v y(t+d t)=v y(t)+\frac{F \sin \theta}{m} d t \\
& \theta(t+d t)=\theta(t)+\omega(t) d t \\
& \omega(t+d t)=\omega(t)+\frac{F z \times r}{I} d t
\end{aligned}
$$

\section{2 反発運動}

パックが壁やストライカーと衝突すると，パックは 反発運動を行う。物体の運動シミュレー夕において, 物体同士の反発運動を計算する場合に利用できる手法 として，大別して三つの剛体運動のシミュレーション 
手法が提案されている。

1つ目は，剛体間に働く接触力を解析的に解くもの である [9]. 運動方程式と拘束条件から接触力を解く手 法であり，お互いに侵入しないという剛体の性質を正 確に再現するが，シミュレーション時において同時に 多数の接触が起こる場合に多くの計算量を必要とする.

2つ目は，剛体が衝突する際に発生する力を撃力に よって表現するものである [10]．衝突時に 2 物体に㗢 く撃力によって抗力を表現する手法であり，衝突が発 生した時刻を求め， 2 物体間の衝突を順に処理する。

この手法は, 1 衝突の処理にかかる計算時間は短いが, 衝突を順番に一つずつ処理するため，短時間に多数の 剛体の衝突が起こる場合には多くの計算時間を必要と する。なお，一般的にこの手法は撃力べース法と呼ば れている.

3つ目は, バネ・ダンパモデルを用いて衝突時に㗢 く力を求める手法[11]である。これは，物体間で衝突 が起きた時，拘束を侵した物体に拘束を侵した量に応 じて，ペナルティとして拘束を侵した物体に力を与え る。この力を与えて反発運動をさせることによって拘 束違反を解消する。またこの手法は，1ステップあた りの計算量が少なくてすむ。 なお，ペナルティに応じ て力を与えるため，この手法はぺナルティ法と呼ばれ ている.

リアルタイムで物体の運動をシミュレーションする 場合には，一定期間のシミュレーションが一定時間に

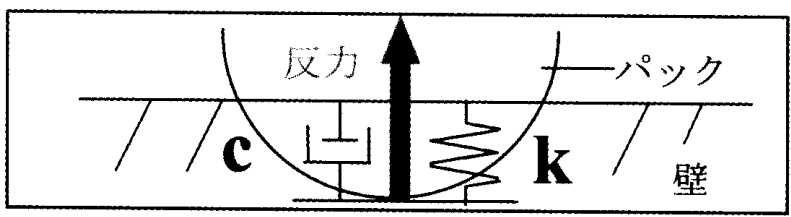

図 8 ペナルティ法

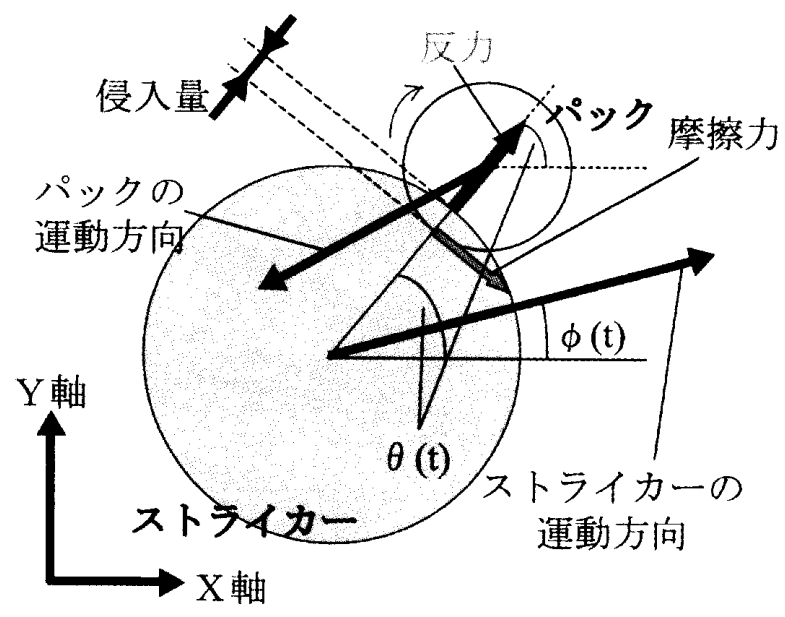

図 9 パックとストライカーの反発

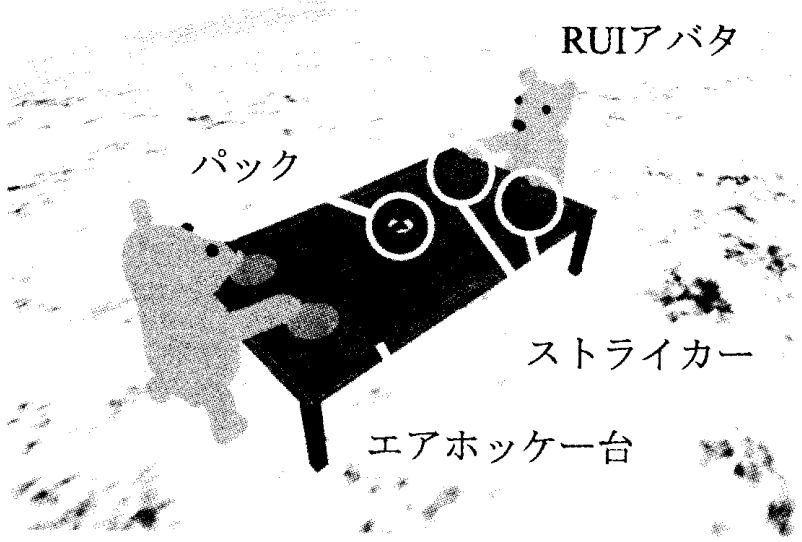

図10 エアホッケー物理モデル

収まらなければならない，1，20手法では計算時間 が多大になる場合や，大きく変動する場合がある。つ まり，この二つの手法はリアルタイムシミュレーショ ンには向かない手法であると言える。

よって，1ステップあたりの計算量が少なくてすみ， リアルタイムシミュレーションを行う上で適している と思われるペナルティ法を使用して，物体衝突時の反 発運動の計算を行った。

\section{5. 運動ルーチンの高速化}

物体同士が衝突した時の反力計算にペナルティ法を 使用したが，ペナルティ法を使用する上で，プログラ 么内で運動を行う時間間隔を短くする必要がある。何 故なら，運動を行う時間間隔が長いと物体の侵入量が 大きくなりすぎ，物体に加える反力も大きくなりすぎ てしまって反発の表現が不安定となるからである。よ って, 運動ルーチンの高速化が必要となる。連動ルー チンをどれだけ高速化させるかの目安としては, 安定 的に物体同士の接触を表現できる最低限の目㚣として の值である $1 \mathrm{kHz}$ (運動の時間間隔が $1 \mathrm{~ms}$ ) とする[12]. また，運動ルーチンのサンプリングレートが $1 \mathrm{kHz}$ よ りも高くなるほど，より硬い物体の力覚を提示するこ とが可能となる。これを受けた力覚提示装置に関する 既存の研究として，より高い更新レートを実現させる ことを目的として赤羽ら [13]は, PC と力覚提示装置の 中間層にハプティックコントローラを配置することで $10 \mathrm{kHz}$ という高速制御を実現し，より硬い物体の力覚 提示に成功した。これを考虑し， $1 \mathrm{kHz}$ より一枌上:回 る $10 \mathrm{kHz} へ の$ 高速化を目標とし, 最低限でも $1 \mathrm{kHz}$ の 高速化を目指した。

な扔，エンタテインメント分野への応用を鑑み出来 るだけ一般的な環境下での高速化を目指し，リアル夕 亿ム OS は用いず Windows 系 OS 上で使える手法を考 
表 2 高速化手法 1 で使用した PC

\begin{tabular}{|c|c|c|c|}
\hline $\mathrm{PC}$ 名 & $\mathrm{CPU}$ & Xモリ & ビデオカード \\
\hline Single1 & $\begin{array}{l}\text { Celeron } \\
1.4 \mathrm{GHz}\end{array}$ & $382.48 \mathrm{MB}$ & $\begin{array}{c}\text { 無L } \\
36.00 \mathrm{MB}\end{array}$ \\
\hline Single2 & $\begin{array}{l}\text { Celeron } \\
1.4 \mathrm{GHz}\end{array}$ & $383.48 \mathrm{MB}$ & $\begin{array}{l}\text { GeForce4 } \\
\text { Ti4800 } \\
124.38 \mathrm{MB}\end{array}$ \\
\hline Dual1 & $\begin{array}{c}\text { P-III } \\
800 \mathrm{MHz} \times 2\end{array}$ & $255.48 \mathrm{MB}$ & $\begin{array}{c}\text { GeForce } 2 \\
\text { MX100/200 } \\
59.12 \mathrm{MB}\end{array}$ \\
\hline Dual2 & $\begin{array}{l}\text { AthlonMP } \\
2400+\times 2\end{array}$ & $510.98 \mathrm{MB}$ & $\begin{array}{c}\text { RADEON } \\
9200 \mathrm{SE} \\
60.28 \mathrm{MB}\end{array}$ \\
\hline
\end{tabular}

案，実装し，実験を行った。

実験には，OS は全てWindows2000で，メモリ，ビ デオカードや CPU 数の異なる複数の PC を使用した。 PC 名は CPU が二つの場合 Duall, CPU が一つの場合 は Single1というようにおいた。

一つ目の高速化手法 1 として, 計算と描画の処理を 分担・並列に行えるように，マルチスレッドとミュー テックスを使用する手法を実装, 実験を行った。実験 方法としては，描画と計算を同時に行うプログラムを 実行し, 計算処理に関して1ループ毎にかかった時間 を計測した。計測したデータは，1ループにかかった 時間が 1 ループに設定した時間の倍の $200 \mu \mathrm{s}$ 以上をエラ 一とみなしそそのエラーの総数を総デー夕数で割った 結果をエラー率とした. また, 力覚提示に最低限必要

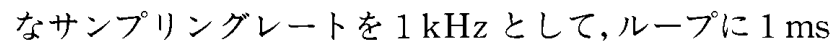
以上かかった場合は別に算出した。

この高速化手法 1 では, SingleCPU の PCではなく DualCPU の PC を使用した場合に, 大幅な速度の向上. が見られた。

二つ目の手法は手法 1 よりも，より一般的な環境下 での実装を考えて SingleCPUのPC での高速化を目指 した，手法としては，プログラム内において描画を更

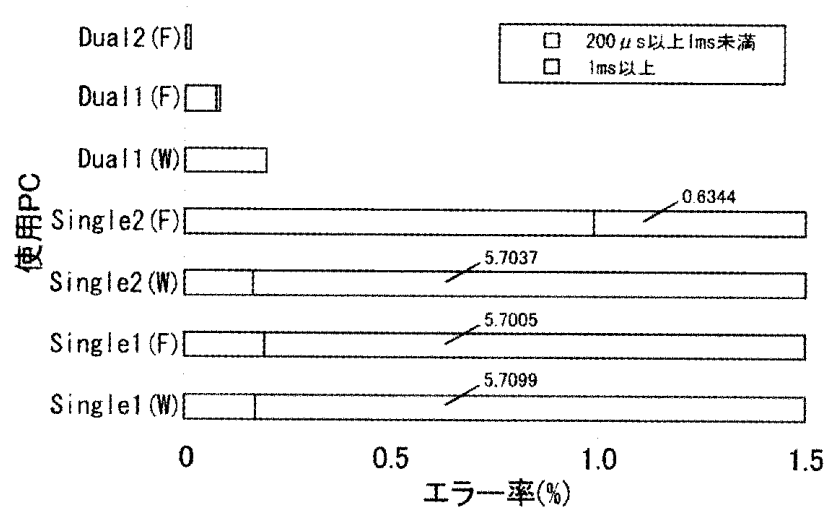

図11高速化手法 1 の結果
新する時に, 前回の描画更新からの経過時間を計算し, その掛かった時間に相当する回数だけまとめて運動処 理を行うものである。この手法 2 により，物理モデル の運動に関しては $1 \mathrm{kHz}$ の高速化は可能になったと言 える。

力党提示は描画の更新レートに依存しており, 本シ ステムでは一般的なレートである $60 \mathrm{~Hz}$ とした。ここで, 力覚提示は力党演算の連続性とその提示タイミングの $2 つ の$ 要素に分けられる. 力党演算の連続性は先の赤 羽らの論文に報告されているように対象物体の硬さの 正確な提示に必要であり，1 kHz 以上にて制御を行う ことが必要である。しかしながらその提示タイミング は視覚や聴鸴等他の感覚統合に関わる問題であり, 視 覚提示の更新レートによる 60 分の 1 秒程度のずれがあ っても違和感は少なくなっている.

また，高速化手法 2 とぺナルティ法を使用した物理 モデル内で, 物体同士の衝突・反発運動に関しての精 度を测定する実験を行った。

実験内容は，一次元運動のみを行う二つの円盤を用 意し，静止している一つの円盤 $\mathrm{A} に$ に对し，ある初速度 を持ったもう一つの円盤 $\mathrm{B}$ を盤 $\mathrm{A}$ に衝突・反発させ る物理モデルを製作する。そして，衝突前と衝突後の

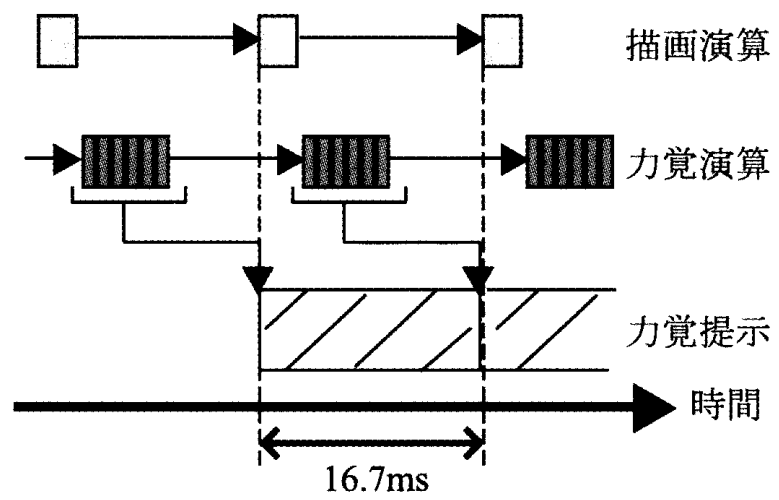

図12高速化手法 2

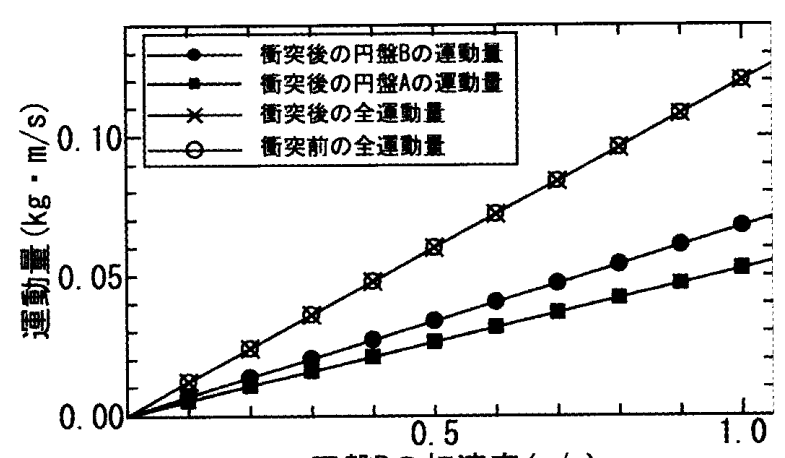

円盤Bの初速度 $(\mathrm{m} / \mathrm{s})$

図13 ペナルティ法を用いた物体同士の衝突反発運動 における運動量の関係 
全体の運動量が保存されているかの計算を行った。計 算結果は以下の通りである。なお，问盤 $\mathrm{A} の$ 質量は40 $\mathrm{g}$, 川盤 Bの質量は $120 \mathrm{~g}$ と設定した。

結果より, 離散的に物体の衝突反発計算を行ってい るにもかかわらず，解析的に計算を行った場合と同様 に物体同士の衝突反発運動の前後で全運動量が保存さ れていることが分かる.よってペナルティ法を使用し， 高速化手法 2 のように運動ルーチンを高速化させるこ とで，正確な運動を行う物理モデルを製作できると考 えられる。

また，バネ・ダンパモデルを使用しているペナルテ イ法では, バネ定数とダンパ定数, 物体の質量, 運動 を行う時間間隔，といった設定值に従って物体同士の 衝突反発運動が行われる。よって, 物体同士の反発係 数を設定することは難しい。しかし，前述したように ペナルティ法では全運動量が保存されているため, 衝 突反発運動の結果から物体同土の反発係数を求めるこ とができ，今回の二つの物体間の反発係数は約 0.75 と 求められた。

\section{6. マルチユーザ型の実装}

エンタテインメント分野におけるマルチユーザ型を 用いたものとしては，同一の場にいる複数人で協力や 対戦を行うもの，ネットワークを通じて遠隔地にいる 複数人で行う MMORPGといったものが挙げられる。 マルチユーザ型のアプリケーションは，ただ情報世界 に対してインタラクションを行うだけでなく，情報世 界と通じて他者とのコミュニケーションを同時に行え るという点で, シングルユーザ型に比べてよりエンタ テイメント性を向上させると考えられる。よって，本 システムに扔いてもマルチユーザ型の実装を行う。

まず, 物理モデル内の RUIアバ夕と, 実世界の RUI を各二体用意することで，二人同時の対戦を可能とし

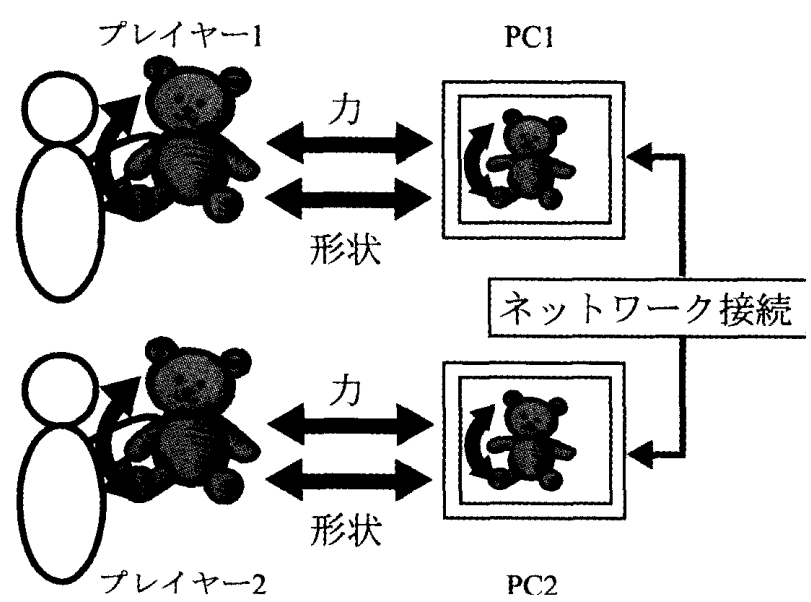

図14 ネットワーク対戦システム構成
た。さらに，一台の PCに二つの RUI を繫ぐのではな く, RUI と PC を各二台用意し，二台の PCをネットワ 一クで結ぶことで, 二人でRUI を用いたエアホッケー の対戦を可能とした．PC間の通信には DirectPlay を 用いた。パックの運動や反発力の計算はサーバー側の PCのみで行い, クライアント側では, RUI の関節角の 情報のみをサーバー側に通信するサーバークライアン トシステムを用いている。

今可は, ローカルネットワーク内の 2 台の PCでサー バークライアントシステムの実装・試験を行ったが, この結果, 描画の更新レートはサーバー側では約 $60 \mathrm{~Hz}$, クライアント側では約 $58 \mathrm{~Hz}$ であった.クライアント側 で若干・描画の更新レートが低下した理由としては次の ことが考えられる、今回の実装したシステムに扔いて， クライアント側ではサーバーから受信するデータに関 して，過去の受信データを全て破棄してから最新のデ 一夕を取得し，その後描画を行うという処理を行って いる。この過去の受信データを全て破充するという処 理により，クライアント側で描画の更新レートが若下 低下したのだと考えられる。操作性や力覚提示に関し ては,サーバー側, クライアント側に繫いだ RUI 共に, シングルユーザ型の時と比較して主観的に变化は感じ られなかった：しかし，グローバルネットワーク内で 2 台のPC を用いる場合には, 通信における時間遅れに よって, RUI と RUI モデルとの形状同期や力覚提示に おいて影響が出ると考えられる。

また，映像のみではなく音という聴覚に対する出力 を用意することで，臨場感を高めることができるので はないかと考えられる。そこで，背景音とパックがス トライカーやエアホッケー台の壁と衝突した時の衝突 音を用意した。衝突音は物理モデルに従って音の大小 を変化させることで現実感を增すように生成している。

\section{7. 結論}

情報空間内でアバ夕が受ける力を物理モデルにより， 実時間で計算することを可能とした。また，計算值に 比例した值を RUIのサーボ動作の目標角に設定して動 作させることで，力覚提示を可能とした。

以上より，RUIを使用することで従来にはない人と 同様の身体性を持った保持型の力覚提示装置を開発し， エンタテインメントの分野においての試験的実装を行 うことができた。

従来のゲームでは，情報世界内のアバ夕を含んだ物 体の運動に関する物理計算はあいまいなものであり， 操作者に対する出力としてはジョイスティックの振動 や抵抗感といったものでしかなかった，近年，オブジ エクトの運動に関して綿密な物理計算を行うゲームが 
増えてきたが，これを活かす出力装置が無いために依 然として振動等でしか出力が行われていない．今回試 験的実装を行ったようにRUI を入出力装置として使用 すると，物理モデルの計算結果を忠実に力として表現 することが可能となる。 それゆえ物理モデルが正確で ある程, RUI の有効性が活かせられると考えられる。 今回試験的実装を行った RUIでは,モー夕とギアによ る関節駆動のために提示できる力の範囲と精度に制約 があったが，今後駆動に精度のよいギアを用いること や，ワイヤー減速機を用いることで正確な力提示を可 能とすることが出来る。また，RUI という操作者とは 「サイズが異なる」インタフェースにおいて，提示す る力の絶対量は計算量のまま返すことが良いのか，ど の程度変化させた方が臨場感の向上に繫がるのかとい う問題が考えられる。

また，本研究の手法では，操作者への力覚提示にお ける更新レートの高速化に関する問題, 情報世界への インタラクションの方法として, RUI モデルに近づい てくる物体に対してインタラクションを行うのみであ り, 操作者自身が情報世界内を自由に移動して様々な 物体へのインタラクションが不可能という問題等が発 生した. 高速化に関しては PC-RUI 間の通信速度の向 上,インタラクション方法に関してはRUI モデルを情 報世界内で移動させるための入力方法の考案・実装, 対応する物理モデルの開発によって解決できると考え られる。

[1] Ishii, H. and Ullmer, B, Tangible Bits: Towards Seamless Interfaces between People, Bits and Atoms, Proceedings of CHI '97, pp.234-241, ACM Press, 1997.

[2] Jun Rekimoto, NaviCam: A Magnifying Glass Approach to Augmented Reality Systems, Presence: Teleoperators and Virtual Environments, Vol. 6, No. 4 pp.399-412, MIT Press, 1997.

[3] 岡田美智雄, 三嶋博之, 佐々木正人編, bit 別冊 : 身体性とコンピュー夕，共立出版，2000.

[4] 関口大陸, 稲見昌彦, 舘日章, オブジェクト指向型 テレイグジスタンスによるロボティックューザインタ フェース 一形状共有システムの提案と試験的実装 一, インタラクティブシステムとソフトウェアVIII：日 本ソフトウェア科学会 WISS2000, 近代科学社, pp. 51-56, 2000 .
[5] Richard Marks, Tany Scovill, Care MichaudWideman, "Enhanced Reality. A New Frontier for ComputerEntertainment”, ACM SIGGRAPH 2001 ConferenceAbstracts and Applications, p. $117,2001$.

[6] Thomas H. Massie, J. K. Salisbury: The PHAN. ToM Haptic Interface: A Device for Probing Virtual Objects, Proceedings of the ASME Winter Annual Meeting, Symposium on Haptic Interfaces for Virtual Environment and Teleoperator Systems, Chicago, IL, Nov. 1994.

［7]佐藤誠, 平田幸広, 川原田弘, 空間インタフェース 装置 SPIDAR の提案, 電子情報通信学会論文誌 DII，J74-D-II-7, pp887-894, 1992.

[8]稲見昌彦, 関口大陸, 川上直樹, 舘日章, RobotPHONEによる物体共有型コミュニケーション，第95 回ヒューマンインタフェース研究会論文集, 2001.

[9] D.Baraff: Analytical Methods for Dynamic Simulation of Non-penetrating Rigid Bodies, Computer Graphics Proceedings (SIGGRAPH 89), Vol.23, pp.223-232, 1989.

[10] B. Mirtich, J. Canny, Impulse-based Simulation of Rigid Bodies, Proceedings of 1995 Symposium on Interactive 3D Graphics, 1995.

[11] M. McKenna and D. Zeltzer: Dynamic simulation of autonomous legged locomotion, Computer Graphics (SIGGRAPH 90), Vol.24, pp.29-38, August 1990.

[12] Lonnie Love and Wayne Book: Contact Stability Analysis of Virtual Walls, Proc. of Dynamic Systems and Control Division ASME, pp.689-694, 1995.

[13］赤羽克仁, 長谷川晶一, 小池康晴, 佐藤誠, $10 \mathrm{kHz}$ 以上の高更新周期を実現する高解像度ハプティックコ ントローラの提案，日本バーチャルリアリティ学会第 8 回大会論文集, pp.7-10, 2003.

[14] 舘日章, ロボット入門, 筑摩書房, 2002.

[15] 舘 日章, バーチャルリアリティ入門, 筑摩書房, 2002 .

[16] 藤井伸旭, 長谷川晶一, 橋本直己, 小池康晴, 佐藤 誠，ペナルティー法を用いた風体運動シミュレータの 開発，日本バーチャルリアリティ学会第 7 回大会論文 集, pp351-354, 2002 .

(2004年 9 月 16 日 受付) (2004年12月21日 採録)

[連絡先]

干182-8585 東京都調布市調布ヶ丘1-5-1

電気通信大学大学院電気通信学研究科 知能機械工学専攻稲見研究室

清水 紀芳

TEL/FAX : 0424-43-5532

Email : shimizu@hi.mce.uec.ac.jp 

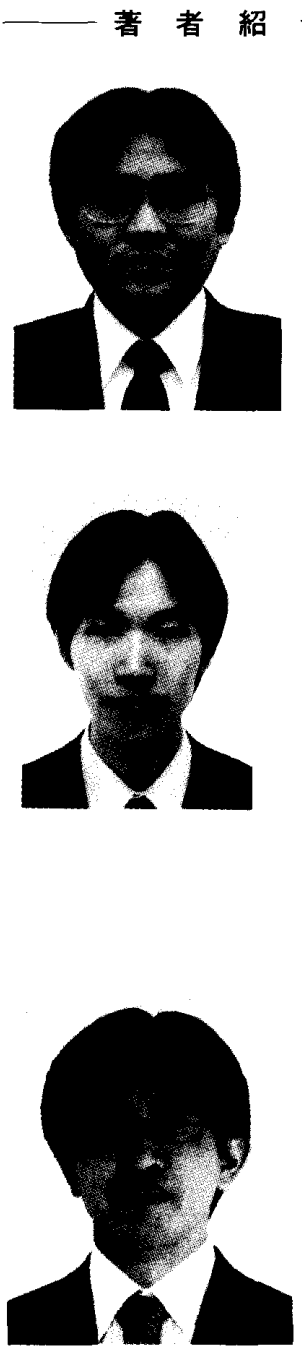

介

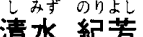

2004年 電気通信大学電気通信学部知 能機械 $[$ 学科卒業. 同年, 同大学大学院 電気通信学研究科知能機械工学専攻に入 学, 現在に至る。ヒーマンインタフェー 又に関する研究に従事。日本バーチャル リアリティ学会学生会員。

\section{杉本麻樹 [排会员]}

2000年 千葉工業大学工学部電子工学 科卒業. 2002年 同大学大学院工学研究科 博士前期課程情報工学専攻修了。问年か ら2003年まで科学技術振興事業団戦略的 創造研究推進事業「協調と制御」領域グ ループメンバー。2003年10月から電気通 信大学大学院電気通信学研究科博士後期 課程機械制御了：学専攻。主に非言語情報 を利用したヒューマンインタフェースに 関する研究に従事。 月本学術振興会特別 研究員, 日本バーチャルリアリティ学会 会員.

\section{関诂势大陸 \\ [非会是]}

2001年 東京大学大学院工学系研究科 博士課程修了, 博士 (工学)。同年より科 学技術振县事業団研究員. 2002年 東京大 学大学院情報理 I学系研究科助手とな り現在に至る。ネットワークロボティク スおよびテレイグジスタンスに関する研 究に従事.

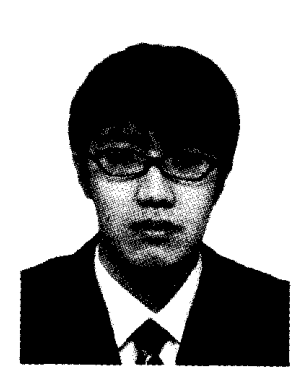

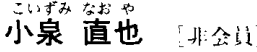

2004年. 電気通信人学電鴙通倍学部知 能機械上学科卒業。间年, 间大学大院 電爹通信学研究科知能機械 1 学曹攻に入

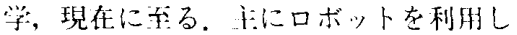
たヒューマンインタフェースに関する研 究に従事. 回本バーチャルリアリティ学 会学特会耑。

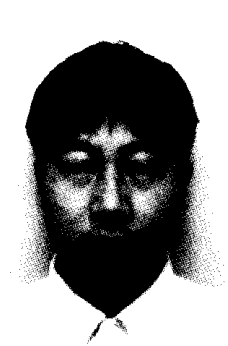

\section{新居 英明 啡金心丁}

1993年 東宗上業大受制御厂学枓 卒業. 1995年闹大学大学院理厂学研究科 博上課程前期課程制御 [ 学尃政修了。间了 年.(株)トキメック入社. 2003年 4 月间社. 退社後(株)テックエキスパーツ入社. 2003 年10月電镉通信大学大学院電氛通信器 研”究科博上:後期課程機械制御 [ 人学、現在に至る。主に光を利用した通 信やヒューマンインタフェースに関する 研究に徒事。日本バーチャルリアリティ 学全学生会是。

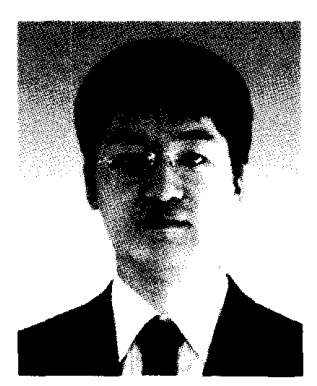

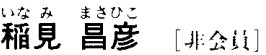

1994年 東京工業大学生命理工学部少: 物 I:学科卒業. 1996年. 间大学院生. 命理 I: 学研究科バイオテクノロジー尃攻修十課 程修了. 1999年 東京人学:工学系研究科先

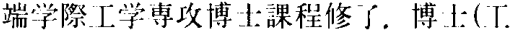
学)。同年より2001年 8 月まで東京大学国 際・産共间研究センターリサーチ・ア ソシエイト。2001年.9月より東京大兴大 学院情報理门学系研究科助手. 2003年. 4 月より䉓攻通信大学知能機械 [学科講 師となり現在に至る。ロボット及びバー チャルリアリティの研究に従事. IEEE Computer Society, 情報処理:学: 月本 ロボット学全, 日本VR受会, 日本VR医 学全各会早。

\section{Teddy bear-like Robotic User Interface}

by

\section{Noriyoshi SHIMIZU, Naoya KOIZUMI, Maki SUGIMOTo, Hideaki NII, Dairoku SEKIGUCHI, Masahiko INAMI}

Abstract :

Robots have chiefly been considered as machines that perform work in the place of human beings, such as industrial robots. However, a robot can be used as an interface between the real world and the information world. This concept can be referred to as a Robotic User Interface (RUI). In this paper, we propose a RUI as a haptic feedback interface. We can interact with information world by using this RUI synchronize a CG model that has the same form and joints as RUI.

Keyword: Robotic User Interface, haptic feedback, entertainment, Virtual Reality

\section{Contact Address : Noriyoshi SHIMIZU}

Graduate School of The University of Electro-Communications

1-5-1 Chofugaoka, Chofu-shi, Tokyo 182-8585 Japan

TEL : 0424-43-5532

FAX : 0424-43-5532

Email : shimizu@hi.mce.uec.ac.jp 